\title{
Research on the Internal Control of Social Responsibility in Low - carbon Tourism Enterprises
}

\author{
Xiaoling $\mathrm{Hu}^{1}$, $\mathrm{Na} \mathrm{\textrm {Liu } ^ { 2 }}$ \\ ${ }^{1}$ College of Management, Wuhan Technology and Business University, Wuhan 430065, China \\ ${ }^{2}$ Hubei Business Development Center, Wuhan 430065, China
}

Keywords: low carbon tourism enterprise, social responsibility, internal control.

\begin{abstract}
On the internal controlof low-carbon tourism enterprise social responsibility, there have been but very few domestic-related academic research. This paper points out the problems of internal control of social responsibility of low carbon tourism enterprises;analyzes thecharacteristics of the internal control, its principles and procedures and finally it points out the methods of internal control of low - carbon tourism enterprises' social responsibility. On the basis of reviewing the existing literature, this article focuses on the development trend of low-carbon tourism enterprises, emphasizes the direction of internal control of tourism social responsibility, and is expectedto promote the academic research and development of internal control of low-carbon tourism enterprises.
\end{abstract}

\section{Introduction}

In recent years, the internal control of corporate social responsibility and other issues have aroused close attention from all our lives. In particular, the tourism enterprises do not addressthe internal control of social responsibility issues of frequent exposure, such as Chinese tourists in South Africa beingrobbed, Yunnan Lijiang tourists beingbeaten, Taiwan tour bus having accident and other phenomena, seriously show the lack of internal control of tourism corporate social responsibility, which ignoresthe rights and interests of people. In fact, the social responsibility of tourism enterprises and internal control are inseparable. What are the causes of these serious social responsibility internal control problems? On one hand, the internal consciousness of the tourism enterprises are not enough; on the other hand, there's lack of control tools.

By public concern, the internal control oftourism corporate social responsibilityhas been controversial. Therefore, it is very important to clarify the characteristics of internal control of social responsibility of tourism enterprises, discuss the principles, procedures and methods of internal control of social responsibility of tourism enterprises. At present, many scholars have explored the problem of internal control of tourism enterprises' social responsibility, but there is still no consistent conclusion. Therefore, this paper will focus on thecharacteristics, principles, procedures, and methods of low-carbon tourism enterprises social responsibility internal control. On the one hand, thestudy enhances the concern of tourism management departments and the public;on the other hand, it provides evidence for enterprises to carry out internal control of social responsibility so that tourism enterprises attach importance to social responsibility internal control and achieve sustainable development.

\section{The characteristics of social responsibility internal control in low-carbon tourism enterprises}

In order to clarify the theoretical problems of social responsibility internal control in low-carbon tourism enterprises, we must first clarify the characteristics of low-carbon tourism enterprises social responsibility internal control, mainly in the following points:

\subsection{Low-carbon tourism enterprise social responsibility internal control formalization}

At present, the internal control system of social responsibility of low-carbon tourism enterprises is based on the internal control standard of low-carbon tourism enterprises, thus the internal control construction in the form is not consistent with the actual situation and will cause the implementation 
problem. In order to make the internal control system play a role in low-carbon tourism enterprises, the existing system should be evaluated to improve the internal control system.

\subsection{Low-carbon tourism enterprises social responsibility of the key points of internal control is not clear}

The key point of the Low-carbon tourism enterprises social responsibility internal control is not clear. Some low-carbon tourism enterprises even still take the accounting control as the key point, that brings many difficulties to low-carbon tourism enterprise internal control work. Only if the Low-carbon tourism enterprises adopt internal control evaluation to find out the key points, we could get twice the result with half the effort in ourfuture work.

\subsection{Implementationof thepoorresults of low-carbon tourism enterprises social responsibility internal control}

The implementation of internal control of social responsibility in low-carbon tourism enterprises is generally poor, the internal control system is not stronglyimplemented. In the evaluation of the low-carbon tourism enterprises social responsibility internal control, the author analyzes the reasons of the ineffective implementation of the internal control system, develops the countermeasures, and improves the implementation of the internal control of low-carbon tourism enterprises.

\section{The objectives and principles of social responsibility internal control in low carbon tourism enterprises}

Social responsibility internal control objectives and principles linked to objectives in low carbon tourism enterprises must effectively follow a certain goal and principles. In view of the goal of low-carbon tourism enterprises social responsibility internal control, the principle of internal control of low-carbon tourism enterprises can be divided into five levels [1].

\subsection{Social responsibility internal control of objectives in low carbon tourism enterprises}

Internal control of high quality and efficiency is the overall goal of low-carbon tourism enterprise internal control, which can guarantee the smooth implementation of low-carbon tourism enterprise strategy, and maximize the value of low-carbon tourism enterprises. In fact, talking about the objectives of internal control of tourism corporate social responsibility is a dual goal, that is, to achieve corporate value and social responsibility. Internal control objectives of low-carbon tourism corporate social responsibility include two aspects:one is the enterprise value, the other oneis the social responsibility control target.Different organizations have different views on the internal control objectives of low-carbon tourism enterprises, butthey all consider the internal control objectives of low-carbon tourism enterprises [2].

Social responsibility of specific objectives of internal control is highly considered inlow-carbon tourism enterprises in order to provide a reasonable guarantee of social responsibility. Strategic control objectives are at the highest level, and other objectives are aligned with strategic control objectives to reach thestrategic control objectives. For example, the strategic control goal is the core and the key, the managing control goal is fundamental to the success of the whole objectives. If there is no management control target, the strategic control objectives are meaningless [3-5]. Low-carbon tourism enterprises in accordance with the macroeconomic environment and micro-environment is neededto achieve management and control objectives, and considerationof the low-carbon tourism business management and social responsibility is required to achieve the operational objectives and social responsibility objectives.

Therefore, the coordination and maintenance of low-carbon tourism enterprises stakeholders can be realized by developing the social responsibility internal control objectivesof low-carbon tourism enterprises. Break down in social responsibility internal control objectives is seen mainly on strategic objectives, management objectives, and operational objectives of the internal control. Different low-carbon tourism enterprises need to cooperate with each other to fulfill the objectives of internal control of social responsibility is different. 


\subsection{Low-carbon tourism enterprises social responsibility of the necessary principles of internal control}

By following the corresponding internal control principles, low-carbon tourism enterprises can achieve social responsibility goals. The principle of Low-carbon tourism enterprises social responsibility, mainly accomplished through the followings:

\subsubsection{The principle of adaptation}

The construction and implementation requirements of low-carbon tourism enterprise social responsibility internal control are forward-looking. Equally noteworthy is that the internal control principle of social responsibility of low-carbon tourism enterprises is compatible with the scale of production, business development and competitive risk. The internal control system can be evaluated in real time, and it can betimely adjusted according to the situation.

\subsubsection{The comprehensive principle}

The comprehensive principle should run through the planning, organization and decision-making, implementation and supervision of the business and matter of the low-carbon tourism enterprises and their affiliated units. In this way, low-carbon tourism enterprise social responsibility internal control can achieve all-round, the whole process and full control without any missing part.3.2.3Important Principle

Important principle is the low-carbon tourism enterprise social responsibility internal control an important part of the key monitoring and takingstrict internal control measures to ensure that no major flaws are in existence. Low-carbon tourism enterprise social responsibility should have a certain professional judgment according to the social environment, market competition and market characteristics,control and management of business as well asthe amount involved.

\subsubsection{The principle of checks and balances}

In the establishment and implementation of internal control, low-carbon tourism enterprises need to follow the principle of checks and balances so that its low-carbon tourism enterprise institutions, corporate decision-making, management framework, business processes, responsibilities, commitment to mutual checks and balances, and mutual supervisiontakeinto account the operation of low-carbon tourism enterprises. Through such non-affiliated posts or links, checks and balances complete the specific business matters; at the same time, low-carbon tourism enterprises canmonitor the responsibilities of the institutions and personnel checks and balances .

\subsubsection{The principle of efficiency}

The costeffectiveness of low-carbon tourism enterprises in the internal controlstartsfrom the best interests of low-carbon tourism enterprises. Therefore, the cost of low-carbon tourism enterprises and the benefits of recovery can be considered in the internal control of cost effectiveness. In spite of this,some low-carbon tourism enterprises internal control measuresmay affect the operational efficiency. However, if the entire low-carbon tourism enterprises suffered large losses, carrying out an internal control should be cost-effective.

\section{Social responsibility internal control proceduresin low-carbon tourism enterprises}

To establish and implement an effective internal control of social responsibilityin the low-carbon tourism enterprises, you can use the following specific contents:

\subsection{Establish a good environment}

Low-carbon tourism business environment,covering the macro environment and micro-environment. The macroeconomic environment is mainly the country's political, economic, scientific and technological, as well as population environment.Themicro-environment mainly involves corporate organizations, governance structure, human resources policy, audit and corporate culture and many others. As the disciplinary and operational structure of low-carbon tourism enterprises, Macroenvironment and micro-environmentcan create a good corporate culture, and always affect the work of employee awareness, acts as the basis of internal control elements. 


\subsubsection{The norms of corporate governance structure}

In China, low-carbon tourism enterprises mainly take "three separate" governance structure, in which shareholders, the board of directors and the board of supervisors are the most obvious. The shareholders'meeting has the decision-making power. The board of directors is responsible for the daily operation and management activities of the low-carbon tourism enterprises. The supervisory authority is vested in the board of supervisors. Only low-carbon tourism enterprises witha standardized governance structurecan guarantee the effective balance of power oflow-carbon tourism enterprises.

\subsubsection{Low-carbon tourism corporate responsibility for the establishment of culture.}

Although low-carbon tourism attaches importance to institutional control, there are human factors in the internal control. As the saying goes, the law can make enterprises ignoreresponsibilities, the system can make employees disobey the rules, morality can make employees achieve corporate culture. As suggested by these social norms, internal control of low-carbon tourism corporate social responsibility may heightenthe sense of morality and responsibility. Yet, to a certain extent, tourism enterprises may have to go beyond the system of checks and balances to achieve the effect.

\subsection{Improve the risk assessment}

With social responsibility internal control,low-carbon tourism enterprises, are empowered to improve risk assessment; that is, low-carbon tourism enterprises can identify, and can analyze business activities, which mightbe associated with internal control objectives. Low-carbon tourism enterprises take effective risk measures, and implement an important part of internal control.

\subsubsection{Identify effective risks}

Within the low-carbon tourism business activities, there is a certain risk. When low-carbon tourism enterprises identify the risk,they should identify the internal and external risks accurately, be consistent with the achievement of the internal control objectives. Low-carbon tourism enterprises need todetermine the appropriate risk toleranceso as to do a good job dealing with the risk.

\subsubsection{Conduct reasonable risk analysis}

The internal control risk analysis of the social responsibility of low-carbon tourism enterprises requires enterprises,scientifically and effectively analyze the professional ethics of management and important posts. If the low-carbon tourism enterprises aim to find problems, and timely take internal control measuresto avoid the personal risk trapsfaced by senior managers, low-carbon tourism enterprises do not necessarily bearany majorproduction and operation losses.

\subsection{Achieve control activities}

Low-carbon tourism enterprises achieve control activities, with specific business and matters, like controlling the corresponding internal control policies, procedures or means. For example, after the risk assessment of low-carbon tourism enterprises is completed, certain measures to control the risk of low-carbon tourism enterprises in a certain range are taken. At this time, low-carbon tourism social responsibility internal control used to achieve control activities can be power, approval, incompatible job separation, budget, operational analysis, accounting system, and performance evaluation control. By strict and normative production process management, Low-carbon tourism enterprisescan achieve and ensure product quality control.

\subsection{Strengthen information and communication}

The information and communication of internal control of low-carbon tourism enterprises aresomeof the important conditions for the success of internal control. Such a successrequires the low-carbon tourism enterprises to transmit information effectively, and is the result of effective communication ensured by internal and external control of low-carbon tourism enterprises. Links of internal control effective communication of low-carbon tourism enterprises include: accurate measurement and record of low-carbon tourism enterprises in the economic business; appropriate disclosure of low-carbon tourism enterprises in the financial, cash flow and operating results; to ensure that low-carbon tourism management and internal and external communication are intact.

\subsection{Strengthen internal supervision}

Low-carbon tourism enterprise social responsibility internal control supervision is the internal control of the effective guarantee, including the usual supervision and special supervision. This 
requires low-carbon tourism enterprises to undertake the construction and implementation of social responsibility internal control, effective monitoring and supervision. Low-carbon tourism enterprise social responsibility of internal control is reasonable, and can be based on internal control loopholes and missed rectification, to ensure the effective operation of the internal control system.

\section{The implementation of the internal control methods of low-carbon tourism enterprises social responsibility}

\subsection{Build a harmonious internal environment of the social responsibility internal control in} low-carbon tourism enterprise

Low-carbon tourism enterprises can exist within the control of the environment, namely the important conditions for internal control. First, pay attention to the internal control system environment of low-carbon tourism enterprises social responsibility. The organizational structure of low-carbon tourism enterprises should balance the relationship between enterprise income and internal control costs to ensure that enterprises can independently balance the power. Second, we can create a low-carbon tourism business responsibility for the internal control of the cultural atmosphere. Social responsibility will be listed in the first place of low carbon tourism enterprises responsibility, and social responsibility into the production and operation of the process, the development of the model can adhere to economic efficiency and environmental as well associal benefits of the model.

5.2 Improve the internal control of risk management awareness of low-carbon tourism enterprise social responsibility

The internal control of risk assessment in low-carbon tourism enterprises is very important. Risk management of low - carbon tourism enterprises' social responsibility is taken as the main prevention. First, according to internal control riskmanagement framework,low-carbon tourism enterprises can identify various risk control, and find out the risks associated with the operation, further to find a way to eliminate the risks through a variety of technologies. Second, carry out regular or irregular product quality inspection and supervision. For example, strengthen the analysis and identification of tourism products and production, circulation and consumption risks by highlighting low-carbon tourism corporate social responsibility internal control, putting an end to irresponsible behavior.

\subsection{Enhance low-carbon tourism enterprise social responsibility internal control activities}

First, building product social responsibility control activities oflow-carbon tourism enterprises can be traced back to the system, so as to promote low-carbon tourism enterprise quality and safety management. Second,low-carbon tourism enterprises establish a responsible crisis management mechanism. In the low-carbon tourism enterprise,the internal control to develop emergency treatment system is recognizable. Once the low-carbon tourism enterprises find production problems, which can bethe first time forthe relevant departments to accurately report the situation, and through the media to the public to publish accurate information to reduce the harm of the product to the community, and establish a responsible low-carbon tourism corporate image.

\subsection{Enhance the internal control of social responsibility information and communication}

Good internal control information disclosure is a necessary condition for low-carbon tourism enterprises to improve the internal control of social responsibility. Low-carbon tourism enterprises within the internal information exchange, that is, the tourism departments of the individual staff bear the responsibility oftimely exchange of low-carbon tourism enterprises in the process of internal and external information as required. For example, low-carbon tourism enterprises canestablish the actual situation of the information management system to ensure that procurement, production, processing, circulation, sales and other aspects of timely and effective feedback.

\subsection{Attach importance to the internal control of social responsibility supervision and evaluation mechanism}

The supervision and evaluation of low-carbon tourism enterprises social responsibility internal control is the guarantee of the effective operation of internal control system. First, in the daily production and management process, low-carbon tourism enterprises supervise the internal control of 
social responsibility, identify and solve the problems; second, they strengthen the management of low-carbon tourism enterprises social responsibility operators. Through direct and indirect supervision, the low-carbon tourism enterprises improve the internal control system and the formation of a good atmosphere. Third, low-carbon tourism enterprises can establish an independent audit system, aninternal control of the risk of regular and irregular review, assess the internal control system, and timely adjust themeasures and means.

\section{Acknowledgments}

This work was financially supported by Hubei Provincial Department of Education research project "low-carbon tourism development path and mechanism of innovation research (16G146)" one of the phased results; Hubei Provincial Department of Education research project "the development of lowcarbon tourism path and mechanism innovation research"(B2016336) one of the stage results; Wuhan Technology and Business University professional core courses (2015HX027)one of the stage results;Hubei business development center project funding (2016Y06) one of the stage results.

\section{References}

[1] Wijk J, Persoon W. A long- haul destination: Sustainability reporting among tour operators [J]. European Management Journal, 2006, 24(6): 381-395.

[2] C.C.Yang, The relationship between international trade and international logisticsc, Int'l Trade. 10(2007)28-31.

[3] Y.Y.Zhang: A study of the relation develpopment between Sino-Thai mutual trade and logistics (2011).

[4] G. Erhard, M. Thompson, Designing with plastics. Munich, Germany: Hanser (2006).

[5] Colliers International. Top European Logistic Hubs. Accessed 05/09/2016. 